\title{
Freshwater Bivalve Molluscs in Artificial Reservoirs of Uzbekistan
}

\author{
Z.I. Izzatullaev, H.T. Boymurodov, A.N. Egamqulov, B.N. Otaqulov, \\ M.B. Xojiyev, Z.A. Bobomurodov and S.A. Suyarov
}

Department of Ecology and Environmental Protection of Nature, Faculty of Natural Science, Alisher Navai State University, Samarkand, Uzbekistan.140104

*Corresponding author

\section{Keywords}

Bivalvia, Hydrobionts,

Article Info

Accepted:

17 November 2019

Available Online:

10 December 2019

\section{Introduction}

The nature and fauna of Central Asian were studied by Russian scientists: P.P. SemyonovTyanshanskiy in 1856-1871, N.A. Seversov in 1864-1878, A.P. Fedchenko in 1868-1879, L.S. Berg in 1940-1949 and others. The monograph Semeystvo Unionidae by Jadin (1938) played an important role in the study of freshwater bivalves in Central Asia.

General information about freshwater molluscs in Central Asia and their zoogeography was reported by Jadin (1950, 1952), Starobogatov (1970) and Izzatullayev and Starobogatov (1985). Many new types of bivalves were introduced to science by Izzatullayev (1980, 1987) during detailed studies of molluscs in Central Asia. This research was summarised in Izzatullayev (2003).

However, it is also important to study bivalve molluscs in artificial water reservoirs near mountains, which represent new possibilities for the expansion of rare, endemic and relict species. It was demonstrated here not only complex extension of special types but also totally fauna complexes, existed difference in different population of one type.

The occurrence of bivalve molluscs in artificial water bodies has resulted in colonisation of new habitats and subsequent range expansion of some species. Theoretical and practical studying of aquatic bivalves, their development and position of extension types in ecosystem are very important. The 
present study therefore focused on the ecology and occurrence in artificial water bodies of freshwater bivalve molluscs in Uzbekistan.

\section{Study areas}

Fieldwork was conducted in three artificial water reservoirs near mountains: 1. Kattakurgan reservoir is situated near the Zirabulok highlands of Zarafshan oasis. Bentos organisms were studied here by N.A. Stepanova, X. Nuriyev and A.I. Ledyayev. 2. Chimkurgan reservoir was formed and activated in a riverbed near the mountain of Kashkadarya in 1959.

Its total area is $49.2 \mathrm{~km}^{2}$, length is $17.2 \mathrm{~km}$ and depth $33 \mathrm{~m}$. The total capacity is 500 $\mathrm{mln} . \mathrm{m}^{3}$. It provides $188 \mathrm{~km}$ of planting areas of Kamashi, Koson, Karshi and Guzor districts with water.

Fish production has also been developed. The reservoir gets water through the Eski Angar (old waterway) canal from the Zarafshan river, which is the route through which bivalve molluscs arrived. 3. Jizzakh reservoir was created around the mountains of Jizzakh region. Its total area is $12.7 \mathrm{~km}^{2}$, depth is 26 $\mathrm{m}$, width is $5.1 \mathrm{~km}$ and its length is $3.3 \mathrm{~km}$.

\section{Materials and Methods}

We began our study of freshwater bivalve molluscs in 1997 because their systematic structure, bio-ecological characteristics and occurrence in Uzbekistan had not been thoroughly investigated.

All materials were collected from the Kattakurgan, Jizzakh and Chimkurgan water reservoirs and their respective inflow and outflow canals in spring, summer and autumn 1997-2009. The occurrence, habitats and spread of distribution of bivalves to artificial water bodies were studied in detail.

\section{Results and Discussion}

\section{Kattakurgan reservoir}

Izzatullayev (1978) reported six species and two subspecies of bivalve molluscs living in this reservoir, among two of them are edentates. ${ }^{1}$ Several species of fish, Balxash okun from Balxash, Xumbosh from the Far East and ok amur (white amur) ${ }^{2}$ were introduced during acclimatization of Kattakurgan reservoir in 1980-1985. Colletopterum ponderosum volgense, Sinanodonta gibba (from China), $S$. orbicularis and $S$. puerorum arrived together with the fish. During our investigation we found that bivalve molluscs brought with fish to artificial reservoirs have adjusted to the new conditions and extended their range.

Molluscs live at a depth of 2.5-3 m or more and can be seen in the bank of the reservoir. Changing water level has an influence on hydrobionts, especially bivalve molluscs. Molluscs feed by filtering water and it can move 20-25 sm distance per hour. The water requirements of agriculture can result in substantial extraction of water from reservoirs and subsequent fall in water level in the summer, which has an influence on molluscs and other hydrobionts.

According to previous studies and the results of the present investigation there are nine species and two subspecies of bivalve molluscs in Kattakurgan reservoir belonging to two families and the peloreofil, pelolimnofil and reofil ecological groups.

Eight species of peloreofil were found in the clay of flow water (Table 1) and in deep argillaceous sediments a subspecies of pelolimnofil, Colletopterum ponderosum volgense, was found. We identified reofil species (Colletopterum bactrianum, C. syreum sogdianum) living in water flow canals 
crossing part of the reservoir (Izzatullayev and Boymurodov 1999, 2000, 2001).

In the gulf of the water reservoir and its right bank live Sinanodonta orbicularis, S. gibba, $S$. puerorum, Colletopterum cyreum sogdianum, C. ponderosum volgensye and Corbicula cor. Of these, Sinanodonta orbicularis, S. gibba and Corbicula cor were most numerous.

In the left bank of flowing water and outflow canals Corbicula cor, $C$. purpurea, Corbiculina tibetensis, C. ferghanensis, Sinanodonta orbicularis and S. gibba are extended 2-4 types of molluscs in $1 \mathrm{~m}^{2}$. Molluscs live at a depth of 0.2-2.8 $\mathrm{m}$ where aquatic plants and cane grow.

Edentates - big Bivalve molluscs, Sinadonta orbicularis, S. gibba (without tooth type Unionidae family)

Balxsh okuni, Xumbosh, ok amur- fish occurring in water reservoirs near mountains in Uzbekistan.

\section{Chimkurgan reservoir}

8 species and 2 subspecies mollusks are extended Chimqurgan water reservoir which created in Kashkadarya region in 1959. Family of Unionidae: S. orbicularis, S. gibba, S.puerorum, C. cyreum sogdianum, C.ponderosum volgensye, from Corbiculidae types: C. cor, C. purpurea, C.fluminalis, $C$. tibetensis, $C$. ferghanensis. Sinanodonta orbicularis, S. gibba, S. puerorum, Colletopterum cyreum sogdianum, C.ponderosum volgensye, Corbicula cor type mollusks live in the gulf and left bank water resevoir. Among them the first, second and the last species are exist more by number.

Corbicula cor, C.purpurea, Corbiculina tibetensis, C.ferghanensis, Sinanodonta orbicularis, S.gibba type mollusks in the left bank and outgoing canals of water reservoir are extended 1-3 species of molluscs in $1 \mathrm{~m}^{2}$ deep. This mollusks are adjusted living in biotope of water reservoirs created by human hands and enlarged extended areal. There are 3 species of ecologic groups of two subspecies mollusks in water reservoir belong to pelolimnofil, pleoreofil and reofil. Among them 8 species of peloreofil, 1 species of reofil and 1 species of pilolimnofil are belonging to ecological group.

The extension of fish have influenced to the extension of two sub species mollusks in the banks of water reservoirs which created by human hand. In the last few years family of Unionidae: Colletopterum bactrianum, $C$. cyreum sogdianum types are getting less.

The reason of their getting less are the level of water fall in water reservoirs and at the period of multiplying mollusks in early spring, the caviar (Glohidias) of the mollusks which left at the bank of nearby water and death of them, a lot small mollusks movement through water to the plant areas by canals from water reservoirs and death of them there.

\section{Jizzakh reservoir}

Eight species of bivalve molluscs were found in this reservoir belonging to two families: Unionidae (Sinadonta gibba, S. puerorum, Colletopterum cyreum sogdianum, $C$. ponderosum volgensye) and Corbiculidae (Corbicula cor, C. purpurea, Corbiculina tibetensis and C. ferghanensis (Table 1).

Molluscs live in two types of habitat. Three types of edentates and $C$. cyreum sogdianum, $C$. ponderosum volgensye and Corbicula cor live in the gulf and left bank of the reservoir. The Corbiculidae as well as Sinadonta gibba occur in moving water and outflow canals. Molluscs live at a depth of $0.2-1.8 \mathrm{~m}$ in places with clay and aquatic plants. 
Table.1 Bivalve molluscs found in artificial water reservoirs near mountains, their ecological and taxonomic characteristics and development

\begin{tabular}{|l|c|c|c|c|}
\hline \multirow{2}{*}{ Species } & \multicolumn{2}{|c|}{ Sites (artificial reservoirs) } & Ecological \\
\cline { 2 - 5 } & Kattakurgan & Chimkurgan & Jizzakh & groups \\
\hline Family Unionidae & & & & \\
\hline Sinadonta orbicularis & + & + & - & Peloreofil \\
\hline S. gibba & + & + & + & Peloreofil \\
\hline S. puerorum & + & + & + & Peloreofil \\
\hline Colletopterum bactrianum & + & - & - & Reofil \\
\hline C. cyreum sogdianum & + & + & + & Reofil \\
\hline C. pondersum volgense & + & + & + & Pelolimnofil \\
\hline Family Corbiculidae & & & & \\
\hline Corbicula cor & + & + & + & Peloreofil \\
\hline C. purpurea & + & + & + & Peloreofil \\
\hline C. flumunalis & + & + & - & Peloreofil \\
\hline Corbiculina tibetensis & + & + & + & Peloreofil \\
\hline C. ferghanensis & + & + & - & Peloreofil \\
\hline Total bivalve species (n): & 11 & 10 & 7 & \\
\hline
\end{tabular}

Note: + present - absent

During detailed studies of bivalve molluscs in artificial water reservoirs near mountainous areas it was found that a total of 8-11 species live in such reservoirs. Three species were found for the first time in artificial reservoirs: Sinanodonta gibba, $S$. orbicularis and $S$. puerorum. Only Unionidae and Corbiculidae were found in water reservoirs in flat lands.

Kattakurgan water reservoir is located in the beautiful area of mountain. That's why different species of molluscs exist there.

Bivalve molluscs extended in water reservoirs such as: Colletopterum bastrianum, C. cyreum sogdianum, Corbicula cor, $C$. purpurea and $C$. fluminalis are entered to The Red Book of the Republic of Uzbekistan (2006) because such species molluscs are rare and endemic. All bivalve molluscs can be considered as good filterers and play an important role in cleaning of water.

\section{References}

Boymurodov Kh. 2002: About extension and ecological groups of bivalve molluscs in Zarafshan river. Kimyogar scientific collection materials. Samarkand. Pp. 57-59.

Izzatullaev Z.I. 1980: Corbiculidae family of bivalve molluscs in Central Asia. Zoo. J., T. 59.pub. 8: 1130-1136.

Izzatullaev Z.I. 1987: Интродуцированные type of freshwater and saltish water mollusks fauna of Central Asia виды пресноводных и солоноватоводных моллюсков фауны Средней Азии. Mollusks. Conclusion and perspectives of studying. C6.8.-L.: Science: 256257. 
Izzatullaev Z.I. 2003: Conclusion and perspectives of studying water molluscs of Central Asia. SamSU, Informational Scientific Research Journal 1: 45-48.

Izzatullaev A.I. and Boymurodov Kh.T 1999: The fauna, ecology, extension and protection of bivalve molluscs in the bank of the Zarafshan river. Material of International scientific conference, Samarkand: SamSU: 66-68.

Izzatullaev A.I. and Boymurodov Kh.T 2000: Transitive water molluscs of Uzbekistan. Journal problems of biology and medicine 4. Samarkand: 76-78.

Izzatullaev A.I. and Boymurodov Kh.T. 2001: Ecology and spread of bivalve molluscs in the basin of the Zarafshan river. Biology - the science of the $21^{\text {st }}$ century. In: $5^{\text {th }}$ Pushin conference of young scientists. 16-20 April 2001. Book of abstracts. Puschino: 234.

Izzatullaev A.I. and Boymurodov Kh.T. 2002: Information about bivalve molluse fauna, ecology and extension of fish farm in Chelek district. SamSU, Informational Scientific research journal 2: 82-83.

Omonov A. and Mirzaev U. 1993: Fish of Uzbekistan. Tashkent. Red Book of the Republic of Uzbekistan, Vol. 2. Animal world: Invertebrates. Fishes. Vermigrade animals. Birds. Mammals- 2 - rewritten and added publication. - T.: Chinor, 2006. 216 pp.

\section{How to cite this article:}

Izzatullaev, Z. I., H. T. Boymurodov, A. N. Egamqulov, B. N. Otaqulov, M. B. Xojiyev, Z. A. Bobomurodov and Suyarov, S. A. 2019. Freshwater Bivalve Molluscs in Artificial Reservoirs of Uzbekistan. Int.J.Curr.Microbiol.App.Sci. 8(12): 2184-2188. doi: https://doi.org/10.20546/ijcmas.2019.812.259 